regularity, and constituting along each gill a kind of grating bearing a close resemblance to the teeth of a comb. The laminæ of which this grating is composed become gradually narrower from their fixed to their free extremities; they are of a dark olive colour, of a hard texture, and highly elastic, but at the same time brittle, and easily snapping off when urged beyond a certain point.

"The office which Mr. Allman assigned to these branchial appendages was that of strainers, by which the water before coming in contact with the branchire is freed from extraneous bodies, which would otherwise interfere with the functions of respiration. The objection which might be urged to this view, namely, that the other sharks are without any such arrangement appeared to him of no weight, as we know but little of the habits of the Basking Shark, and as those which we do know would lead us to believe that the structure just described is admirably adapted to the fish's peculiar mode of life. The Basking Shark must be entirely free from the voracious disposition so characteristic of the allied genera. Its teeth are little more than tubercles, and quite unfit it for the life of carnage led by other sharks. Its food must accordingly be found among the less resisting inhabitants of the ocean; and as the Basking Sharl will therefore be driven to feed near the bottom and among seaweeds the existence of the branchial appendages will admit of an easy explanation. We must thus at once perceive the admirable adaptation of this interesting arrangement to the habits of an animal which would otherwise be subjected to the constan annoyance of having its branchire clogged with the floating fronds of sea-weeds, a circumstance which the anatomical structure alone would otherwise render more liable to occur in this than in the other sharks, as the openings to the branchiæ in the Selachus maximus are of enormous size, and the branchiostegous membranes particularly loose."

Geo. J. Aliman

\section{The Birds of Kerguelen Island}

My attention has been called to a review of Dr. Kidder's "Report on the Ornithology of Kerguelen Island," in NATURE of the roth instant ( $\mathrm{p} .3 \mathrm{I} 7$, supra). Will you kindly permit me to express reoret that the reviewer should have alluded to pri ority of publication of the results of the American and English expeditions to that island? To many persons his remarks on this point will appear to be ungenerous and needlessly sarcastic to the foreign naturalists. The subject is a delicate one, and I am sorry to have occasion to mention it, especially as an Englishman should be the last to approach it.

The reviewer will doubtless admit that when three naturalists are simultaneously sent to work independently of one another in the same neighbourhood, it is almost inevitable that one will anticipate the work of the others, and yet that there is nothing to boast of if he does. In the present instance, being bound to regard the interests of my employers in my collection, I hastened the issue of preliminary diagnoses of the novelties contained in it, to secure their types from alienation to foreign museums. The result of this was the acquisition by the English of the types of all the new species in my collection excepting those of one bird (which lias recently been described as new by the Germans), and those of two Annelids, and three lichens, and perhaps a moss pre-occupied by the Americans. We could well have afforded to lose nine or ten times as many, and should still have retained a fair proportion of the whole number for English museums. The reviewer, therefore, might have done well if he had censured the rapacity of the English in grasping the lion's share of the type-specimens ; but it was rather grasping the lion follow-workers small feelings of jealousy with reference to the Americans being the first in the field with their final reports, of which they are not conscious. The Americans have kept us fully informed as to the progress of their reports during the period of their preparation, by letter and by the transmission of advance sheets; and the English final reports will no doubt be ready at the time appointed by the Royal Society. If the Germans publish their results in the meanwhile, we shall have the advantage of including references to their work among our citations.

The reviewer is perhaps unaware of the publication of another Bulletin by the Americans, containing, amongst other information relating to Kerguelen Island, further ornithological particulars. It was issued more than a month ago.

A. E. Eaton

Naturalist accompanying the Eaglish Transit of Venus Expedition to Kerguelen Island in 1874

\section{Antedated Books}

I AM ready to give the Editor of the Zoological Society's Transactions credit for desiring to set a good and not a bad example ; but, since a man seldom thinks that which he does to be wrong, the simple assertion of his opinion that it is the former and not the latter is not enough. Whether the papers in those Transactions are antedated by one month (as he admits) or by several months is merely a matter of detail. The practice of antedating is equally faulty in principle. If their editor would add the correct date of publication on the covers of the several parts, as is done with the Proceeding's of the Royal and the Fournal of the Linnean Society, he might give whatever date he pleases anywhere else as that of his latest revision.

ANOTHER F.Z.S.

\section{Earthquake in Nithsdale, Scotland}

ON the morning of the I2th current, at 3 o'clock, Mr. Robson, of the schoolhouse of Penpont, Dumfriesshire, was awakened by a sharp shock of earthquake and heard its detonations. On inquiry the same shock had been felt at the schoolhouse of Tynron, by Mr. Laurie; and over an area of several parishes around the upper course of the Nith the shock was felt, causing walls to vibrate and cupboard dishes to tingle. Two concussions of less violence were felt between Ir and I2 o'clock on the previous evening. The morning papers of the isth report that a severe shock of earthquake had been felt at $A$ thens on the morning of the 12 th. It would be interesting to know the exact time when the shock was felt in Greece. On April 16th, 1873, at 9.55 P.M., a similar shock to that experienced last week was felt in the same districts of Nithsdale, I recollect communicating a short notice of it to NATURE at the time, as I had heard the strange sound, but on this occasion $I$ did not hear it.

Tynron Schoolhouse, Aug. 23

JAMES SHAW

P.S.--Since writing the above I have received confirmation of the event from several other reliable witnesses. It seems to have been most plainly felt in the parishes of Morton, Penpont, Keir, Tynron, and Glencairn, to the west of the Nith. J. S.

\section{The Cuckoo}

THE usual manner in which the cuckoo in June "alters his tune," is by doubling his first syllable, and the "cuc-cuckoo, cuc-cuckoo" is then usually, if not always, followed by the single "cuc." This is certainly the case both near London and in the Midlands.

E. H. ABSTRACT REPORT TO "NATURE" ON EX.
PERIMENTATION ON ANIMAIS FOR THE ADVANCE OF PRACTICAL MEDICINE ${ }^{I}$

VII.

THERE occur to me a few other illustrative series of researches, in which scientific and practical medicine have been advanced by experimentation on the lower animals. Some of these I will state in terms as brief as possible in the present paper.

Experimentation in respect to the Disease called Cataract.

Dr. Weir Mitchell, of Philadelphia, in the year 1869 , made the original and remarkable observation that if a part of the body of a frog be immersed in simple syrup, there soon occurs in the crystalline lens of the eyeball an opaque appearance resembling the disease called cataract. $\mathrm{He}$ extended his observations to the effects of grape sugar, and obtained the same results. He found that he could induce the cataractic condition invariably by this experiment, or by injecting a solution of sugar with a fine needle, subcutaneously, into the dorsal sac of the frog. The discovery was one of singular importance in the history of medical science, and explained immediately a number of obscure phenomena. The co-existence of the two diseases, diabetes and cataract, in man, had been observed by France, Cohen, Hasner, Mackenzie, Duncan, von Graafe, and others, and von Graafe had stated that after examining a large number of diabetic patients in different hospitals, he had found one-fourth affected with cataract. Before Mitchell's observation there was not ${ }^{x}$ Continued froin $\mathrm{p}, 34 \mathrm{I}$, 